ADELA GARCIA-ARACIL, JOSE-GINES MORA AND LUIS E. VILA

\title{
THE REWARDS OF HUMAN CAPITAL COMPETENCES FOR YOUNG EUROPEAN HIGHER EDUCATION GRADUATES
}

\section{INTRODUCTION}

The concept of human capital is the idea that people spend on themselves in diverse ways, not for the sake of present enjoyment, but for the sake of future monetary and nonmonetary returns. They may purchase health care; they may voluntarily acquire additional education; they may spend time searching for a job with the highest possible rate of pay, instead of accepting the first offer that comes along; they may purchase information about job opportunities; they may migrate to take advantage of better employment opportunities; and the may choose jobs with low pay but high learning potential in preference to dead-end jobs with high pay. All these phenomena - health, education, job search, information retrieval, migration, and in-service training - may be viewed as investment rather than consumption, whether undertaken by individuals on their own behalf or undertaken by society on behalf of its members.

Consequently, education represents more than an investment in human capital (Becker 1993) because it allows individuals to learn and acquire skills that will fundamentally shape their behaviour, beliefs and role in society (Haveman \& Wolfe 1984). Education appears to be related to people's success in making many economic decisions; longer schooling, in particular, promotes more efficient decision-making processes related to the labour market through the acquisition of information that has a positive impact on personal choices (Arrow 1997).

Evaluations of the appropriate level of investment in schooling have typically focused on market outcomes, particularly labour market returns. The relationship between earnings and schooling has been widely studied at both the theoretical and empirical levels. The relationship is simple to state: more educated people enjoy a higher level of earnings than people with a lower level of education. Longer schooling and training improve the chances of employment (Iyigun \& Owen 1999; Rivera-Batiz 1992), reduce unemployment duration (Kettunen 1997; Kiefer 1985) and positively influence income through higher labour market 
earnings. The estimation of monetary returns from education has generated a vast amount of literature and is becoming increasingly sophisticated (Card 1999; Cohn \& Addison,1998; Psacharopoulos 1994). However, as early work by Weisbrod (1964) pointed out, it is clear that traditional monetary measures do not capture all the utility-enhancing effects of education. Education also provides for increased utility over time in the form of increased productivity, greater capacity to enjoy things derived from leisure, and so on (Haveman \& Wolfe 1984; McMahon 1998).

In addition, personal characteristics such as talent, education and experience determine how well a person performs, and thereby that person's productive value in the labour market (Becker 1964). When graduates of certain programmes enjoy greater success in the labour market than graduates of other programmes, this is normally attributed by human capital theorists to differences in the quality of education. There are however other theories that can explain the observed differences. For example, Thurow's (1975) theory of the labour queue (otherwise known as the job competition model) states that productivity is primarily determined by job characteristics. Personal characteristics such as the course of education followed have no direct effect on productivity, but are important as criteria for recruitment and selection. Employers prefer graduates of certain courses because they expect these graduates to require less training costs than graduates of other courses.

A good programme can be important, not only for preparing graduates for a high level of performance on entry to the labour market, but also for employability in the longer term. That is why more attention has been paid in recent years to the importance of various types of competences in the labour market. Competences, understood as those talents, skills and capabilities of graduates that contribute to productivity gains, are perceived as a key element for sustainable economic growth and development in the globalised economy (Hartog,1992). Increasingly, policy makers are focusing on the relevance of human capital competences. The reason is that workers with sufficient and up-to-date competences are more productive and have more potential to remain employed (Buchel 2002). The introduction of a new technology changes the nature of work, which affects the relative importance of various tasks. Technological change is also deemed to induce upward biases in the demand for competences. Some of the competences that workers have accumulated will become less relevant, while others will become more important. The changes include increases in both the supply of and demand for highly skilled or educated workers, significant increases in the 
returns to schooling, and the apparent introduction of non-neutral technology that disproportionately benefits more educated individuals.

These changes have raised new concerns about the accuracy of the match between higher education and employment of graduates in Europe (Teichler \& Kehm 1995; Witte \& Kalleberg 1995; Heijke, Meng \& Ris 2002). Among these concerns, there are two that focus the attention of researchers. The first one is the identification of those competences that are more relevant to graduates' professional success (Busato, Prins, Elshout \& Hamaker 2000; Heijke, Meng \& Ramaekers 2002). The second is whether and how these competences are generated (or may be better promoted) through higher education systems (Dolton \& Makepeace 1990; Pike 1995; Leckey \& McGuiga 1997; Belfield, Bullock \& Fielding 1999). It is far from easy to give a clear answer to these questions because of the heterogeneity and changing nature of productivity-enhancing characteristics of graduates.

Discussions on competences often emphasise the importance of certain skills and blame the educational system for inadequately providing them. In the debate on occupation-specific versus general education and training, Bishop (1995) advocates that education should focus on occupation-specific skills rather than on general academic skills. He departs from the premise that academic skills are mere tools for developing specific skills but not a good substitute for occupation-specific skills. Although later, Bishop and Kang (1989) argue that for high school graduates who enter the labour market vocational and academic education in high school are complements rather than substitutes. Other research literature tends to find stronger positive effects of vocational course work on labour market outcomes (Campbell \& Laughlin 1991). But, while Bishop stresses the importance of occupation-specific skills, other authors underline the importance of general (or generic) skills (Bowen 1977).

Competences are often classified according to the extent to which their application is related to a particular context, such as a job, a firm or an occupation. A well-known classification of competences is Becker's (1993) distinction between general and firm-specific competences. Nordhaug (1993) has further refined and extended Becker's classification by distinguishing between competences that are specific to firms (firm-specificity), tasks (task specificity) and economic sectors (industry specificity). Heijke, Meng and Ramaekers (2002) distinguish three groups of competences, those acquired in school, which are of direct use in later work, those acquired in school which facilitate acquiring new competences after graduation from school, and those competences acquired mainly in a working context. 
Kellermann (2003) classifies the competences according to five groups, featuring an academic personality, general-academic (represented through the competence broad general knowledge), scientific-operative (represented through accuracy, attention to detail), personalprofessional (represented through field-specific knowledge of methods), social-reflexive (represented through leadership) and physiological-handicraft (represented through manual skills). Bunk (1994) aggregates competences into four different groups: specialised, methodological, participative and socio-individual. Other classifications are ad hoc, in the sense that they are made according to the data availability for particular purposes (Allen \& van der Velden 2001). Thus, there is not a general agreement about classifying competences nor theory provides a clear classification of competences.

This paper contributes to the discussion on competences. The objective of this paper is to analyse the incidence of different groups of competences in the graduates' payoff both in terms of income (monetary rewards) and job satisfaction (which includes the non-monetary rewards as well). The paper is organised as follows: the next section covers data and methodology; the third section presents the results; and the final section provides conclusions and implications for policy makers.

\section{DATA AND METHODOLOGY}

Data

The data set used in this paper was taken from a major representative survey comparing the situation of European higher education graduates. More than 36,000 graduates holding a first higher education degree were surveyed about four years after graduation (graduates from 1995 were surveyed in 1999). The study, named CHEERS (Careers after Higher Education - A European Research Survey), included graduates from eleven European countries: Italy, Spain, France, Germany, Austria, The Netherlands, United Kingdom, Finland, Sweden, Norway and the Czech Republic (for a full description of the survey, see Schomburg \& Teichler, 2004; Teichler \& Schomburg, 2004).

Among other questions, the CHEERS survey addressed information with respect to 36 different items representing demands for and supplies of competences. Graduates were asked to indicate on a five-point ordered scale the extent to which they possessed a given competence at time of graduation (the acquired level of competence) and the extent to which this given competence was required in their current work (the required level of competence). 
Classification and competences

Since competences are connected with a meaningful connotation, we tried to make the data more transparent and to overcome the multicolinearity problem found among the long list of 36 competences available in our sample. For that purpose, we applied a factor analysis to the list of required competences, whereas the individual was more likely to refer to his/her actual job content. Factor analysis provides factor scores completely uncorrelated with each other, which permits us to classify the competences into eight main orthogonal categories. These eight factors accounted for the $53.9 \%$ of the overall variance.

We have defined these factor groups (Table 1) as follow. Participative competences are held by those who are able to contribute towards constructing the working environment at their own workplace and beyond, can plan ahead, assume tasks, take decisions and are willing to assume responsibility. Those who are able to react to problems they are set and to deviations from the norm in a manner that is appropriate, using the procedure expected, who can apply experience gained to find sensible solutions to other problems hold methodological competences. Specialised competences are held by those who are able to carry out activities and tasks in their field of work in a responsible and competent manner and possess the required knowledge and skills to do so. Organisational competences are held by those who are able to work under pressure, with attention to detail and independently (the original factor scores are reversed for ease of interpretation). Applying-rules competences refer to applying rules and regulations, and are negative related to creativity. Physical competences contain items related with manual skills and fitness for work. Generic competences can be defined as those competences that can be applied across a broad range of contexts. This indicates that the term generic competences include more than just general knowledge in a strict sense; it also includes critical thinking and oral and written communications skills. Finally, those who are able to work cooperatively with others and who show team-oriented behaviour and interpersonal understanding hold socio-emotional competences. 
Table 1. Categories of Competences.

\begin{tabular}{|c|c|}
\hline Participative & Methodological \\
\hline $\begin{array}{l}\text { Planning, coordinating and organising } \\
\text { Negotiating } \\
\text { Initiative } \\
\text { Assertiveness, decisiveness, persistence } \\
\text { Getting personally involved } \\
\text { Leadership } \\
\text { Taking responsibilities, decisions }\end{array}$ & $\begin{array}{l}\text { Foreign language proficiency } \\
\text { Computers skills } \\
\text { Understanding social, organisational systems } \\
\text { Economic reasoning } \\
\text { Documenting ideas and information } \\
\text { Problem-solving ability } \\
\text { Analytical competencies }\end{array}$ \\
\hline Specialised & Organisational \\
\hline $\begin{array}{l}\text { Field-specific theoretical knowledge } \\
\text { Field-specific knowledge of methods }\end{array}$ & $\begin{array}{l}\text { Learning abilities } \\
\text { Working under pressure } \\
\text { Accuracy, attention to detail } \\
\text { Time management } \\
\text { Working independently } \\
\text { Power of concentration }\end{array}$ \\
\hline Applying-rules & Physical \\
\hline $\begin{array}{l}\text { Applying rules and regulations } \\
\text { Low requirement of creativity }\end{array}$ & $\begin{array}{l}\text { Fitness for work } \\
\text { Manual skills }\end{array}$ \\
\hline Generic & Socio-emotional competences \\
\hline $\begin{array}{l}\text { Broad general knowledge } \\
\text { Cross-disciplinary thinking/knowledge } \\
\text { Critical thinking } \\
\text { Oral communications skills } \\
\text { Written communications skills }\end{array}$ & $\begin{array}{l}\text { Reflective thinking, assessing one's own work } \\
\text { Working in a team } \\
\text { Adaptability } \\
\text { Loyalty, integrity } \\
\text { Tolerance, appreciating of different point of view }\end{array}$ \\
\hline
\end{tabular}

According with this classification for competences, we present in Table 2 the numerical values of the 36 original items for both acquired and required competences. The acquired level of competences offers information about graduates' self-assessment on the amount of competence built up during their higher education, while the level of competences required offers self-reported measures about the requirements of graduates' current job. The use of such criteria has the advantage of rising information from the closest source to the actual job situation, taking into account all specific circumstances. 
Table 2. Descriptive Statistics for Competences

\begin{tabular}{|c|c|c|c|c|c|}
\hline & \multicolumn{2}{|c|}{ Acquired } & \multicolumn{2}{|c|}{ Required } & \multirow{2}{*}{$\frac{\text { Difference }}{\text { (acq- req) }}$} \\
\hline $\begin{array}{r}\text { Participative } \\
\end{array}$ & Mean & Std. Dev. & Mean & Std. Dev. & \\
\hline Planning, coordinating and organising & 3.11 & 1.05 & 4.11 & 0.95 & -1.00 \\
\hline Negotiating & 2.58 & 1.05 & 3.66 & 1.15 & -1.08 \\
\hline Initiative & 3.51 & 0.98 & 4.11 & 0.89 & -0.60 \\
\hline Assertiveness, decisiveness, persistence & 3.50 & 0.99 & 4.14 & 0.84 & -0.64 \\
\hline Getting personally involved & 3.79 & 0.96 & 4.07 & 0.92 & -0.28 \\
\hline Leadership & 2.83 & 1.06 & 3.57 & 1.14 & -0.74 \\
\hline Taking responsibilities, decisions & 3.38 & 1.02 & 4.23 & 0.88 & -0.85 \\
\hline \multicolumn{6}{|l|}{ Methodological } \\
\hline Foreign language proficiency & 3.06 & 1.11 & 2.90 & 1.38 & 0.16 \\
\hline Computer skills & 2.97 & 1.14 & 3.80 & 1.12 & -0.83 \\
\hline Understanding complex systems & 2.79 & 1.02 & 3.32 & 1.17 & -0.53 \\
\hline Economic reasoning & 2.75 & 1.14 & 3.50 & 1.20 & -0.75 \\
\hline Documenting ideas and information & 3.28 & 1.05 & 3.81 & 1.05 & -0.53 \\
\hline Problem-solving ability & 3.62 & 0.90 & 4.30 & 0.79 & -0.68 \\
\hline Analytical competencies & 3.68 & 0.91 & 3.95 & 0.96 & -0.27 \\
\hline \multicolumn{6}{|l|}{ Specialised } \\
\hline Field-specific theoretical knowledge & 3.82 & 0.93 & 3.68 & 1.13 & 0.14 \\
\hline Field-specific knowledge of methods & 3.41 & 1.00 & 3.67 & 1.14 & -0.26 \\
\hline \multicolumn{6}{|l|}{$\begin{array}{c}\text { Organisational } \\
\end{array}$} \\
\hline Learning abilities & 4.18 & 0.76 & 4.03 & 0.90 & 0.15 \\
\hline Working under pressure & 3.53 & 1.08 & 4.29 & 0.89 & -0.76 \\
\hline Accuracy, attention to detail & 3.70 & 0.98 & 4.14 & 0.86 & -0.44 \\
\hline Time management & 3.30 & 1.04 & 4.14 & 0.87 & -0.84 \\
\hline Working independently & 3.95 & 0.95 & 4.33 & 0.86 & -0.38 \\
\hline Power of concentration & 3.95 & 0.85 & 4.05 & 0.84 & -0.10 \\
\hline \multicolumn{6}{|l|}{ Applying-rules } \\
\hline Applying rules and regulations & 2.95 & 1.09 & 3.59 & 1.12 & -0.64 \\
\hline Low requirement of creativity & 3.38 & 1.04 & 3.72 & 1.09 & -0.34 \\
\hline \multicolumn{6}{|l|}{ Physical } \\
\hline Fitness for work & 3.62 & 1.06 & 3.90 & 1.04 & -0.28 \\
\hline Manual skills & 2.96 & 1.21 & 2.88 & 1.34 & 0.08 \\
\hline \multicolumn{6}{|l|}{ Generic } \\
\hline Broad general knowledge & 3.70 & 0.82 & 3.62 & 1.00 & 0.08 \\
\hline Cross-disciplinary thinking/knowledge & 3.39 & 0.88 & 3.65 & 1.01 & -0.26 \\
\hline Critical thinking & 3.76 & 0.94 & 3.90 & 0.96 & -0.14 \\
\hline Oral communication skills & 3.62 & 0.99 & 4.30 & 0.83 & -0.68 \\
\hline Written communication skills & 3.85 & 0.90 & 4.06 & 0.96 & -0.21 \\
\hline \multicolumn{6}{|l|}{ Socio-emotional competences } \\
\hline Reflective thinking, assessing one's own work & 3.52 & 0.94 & 3.95 & 0.91 & -0.43 \\
\hline Working in a team & 3.65 & 1.04 & 4.19 & 0.93 & -0.54 \\
\hline Adaptability & 3.74 & 0.94 & 4.11 & 0.83 & -0.37 \\
\hline Loyalty, integrity & 3.83 & 1.05 & 4.06 & 0.93 & -0.23 \\
\hline Tolerance, appreciating of different points of view & 3.70 & 0.95 & 3.96 & 0.92 & -0.26 \\
\hline
\end{tabular}

On average, graduates reported having lower levels of competences than those required for their jobs. The lowest value for a similarity between acquired and required level of competence corresponds to 'negotiating', that is, this competence shows the highest deficit. Nevertheless, there are five items that received high assessments concerning the list of acquired competences: 'foreign language proficiency', 'learning abilities', 'field-specific theoretical knowledge', 'manual skills' and 'broad general knowledge'. It must be pointed out that the jobs where young graduates are occupied require a lower level of such general competences. 
Empirical model

For the purpose of this paper, to analyse the effects of these eight-competence-categories requirements on graduates' income and job satisfaction, we estimated a conventional earning regression for income using OLS estimation and an ordered probit regression for job satisfaction to reflect the ordinal character of the answers on job satisfaction scores (Green 1997). In the case of income, this is a continuous variable and a standard regression model will give us the weight if the different variables. In the case of the analysis of job satisfaction, a ordered multi-response model (such as probit) is necessary due to the discrete character of the variable rating job satisfaction.

As explanatory variables we use indicators of the required level of competences, with control variables for personal characteristics, job attributes, occupational titles, fields of study, and dummies for each country and for the distinction between university institutions and other higher education institutions. As job main attributes, we used working hours and the size of firms. As public sector employment, full-time jobs and permanent contracts have specific characteristics that many people consider desirable, we also included a dummy variable for each of them. Personal characteristics such as age and gender were also included in the regressions. We made the distinction between university institutions and other higher education institutions to test possible differences between the effects of both types of institutions on the career of graduates. We also included dummy variables representing the occupational titles, fields of study, and countries.

RESULTSEffects of competences on incomeTable 3 shows the results for a conventional earning regression where the dependent variable is gross annual income. There were in fact differences among the competence-categories considered. We observe that participative and methodological competences seemed to be much more important than the rest of competences in order to explain income differences. One standard unit increase in the required level of participative competences yielded to an income increase of about $5.8 \%$, whereas a similar increase in the required level of methodological competences yielded to an income increase of some $4.9 \%$. Generic and socio-emotional competences had a similar, but smaller, effect on income. With respect to specialised competences, the income analysis shows that the required level does not have a significant effect. This latter result must be carefully interpreted, due to the fact that we included in our analysis occupational titles as control variables. A separate analysis (not shown here) without considering occupational titles 
showed a significant positive effect of specialised competences on income. Therefore, the analysis shown in Table 3 indicates that the type of job performed mediates the effect of specialised competences on income. On the other hand, applying-rules and physical competences had negative effects on income. In the case of physical competences, one is tempted to guess that jobs that required manual skills and fitness for work were not typical graduates' jobs and consequently salaries were lower. Similarly, jobs requiring a rigid application of rules along with a low level of creativity were also more likely to be found at lower levels than at graduates' one. Finally, organisational competences had a negative effect, which might indicate that these competences are not rewarded in the first years of a graduate's professional career.

With respect to occupational titles, the model provides the expected evidence that individuals working in more demanding jobs had higher incomes. When we explore the segmentation of the different educational fields, we note that graduates in Education, Humanities, Social Science, Law and Natural Sciences had lower income than graduates in the reference category (Engineering). However, Mathematics (data processing and computer specialists included) and Medical Sciences graduates earned more than Engineers. Finally, having followed university education rather than other higher education institutions yielded to a significant increase in income of about $3 \%$. 
Table 3. OLS Parameter Estimates for Annual Gross Income

\begin{tabular}{|c|c|c|}
\hline & Coeff & t-values \\
\hline \multicolumn{3}{|l|}{ Required Competences } \\
\hline Participative & $0.058^{\star \star}$ & 19.125 \\
\hline Methodological & $0.049^{\star *}$ & 15.334 \\
\hline Specialised & 0.002 & 0.742 \\
\hline Organisational & $-0.010^{* *}$ & -3.176 \\
\hline Applying-rules & $-0.012^{\star \star}$ & -3.978 \\
\hline Physical & $-0.036^{\star \star}$ & -11.096 \\
\hline Generic & $0.013^{\star \star}$ & 4.312 \\
\hline Socio-emotional & $0.010^{\star *}$ & 3.246 \\
\hline \multicolumn{3}{|l|}{ Personal Characteristics } \\
\hline Female & $-0.064^{\star \star}$ & -10.786 \\
\hline Age & $0.012^{\star \star}$ & 8.116 \\
\hline \multicolumn{3}{|l|}{ Job Characteristics } \\
\hline Hours worked per week & 0.259 ** & 19.021 \\
\hline Private sector & $0.071^{\star *}$ & 10.743 \\
\hline Small firm & $-0.145^{\star \star}$ & -20.734 \\
\hline Full-time job & $0.261^{\star *}$ & 22.521 \\
\hline Permanent contract & $0.127^{\star \star}$ & 17.290 \\
\hline \multicolumn{3}{|c|}{ Occupational titles (ref. elementary occupations) } \\
\hline Legislators, senior official and managers & $0.190^{\star \star}$ & 16.446 \\
\hline Professionals & $0.139 \star *$ & 16.282 \\
\hline Technicians and associate professionals & $0.088^{\star \star}$ & 8.318 \\
\hline Clerks & -0.012 & -0.832 \\
\hline Service workers & -0.014 & -0.582 \\
\hline \multicolumn{3}{|l|}{ Field of Study (ref. Engineering) } \\
\hline Education & $-0.074^{\star *}$ & -5.378 \\
\hline Humanities & $-0.128^{\star \star}$ & -12.220 \\
\hline Social Sciences & $-0.038^{\star \star}$ & -4.705 \\
\hline Law & $-0.108^{\star \star}$ & -8.732 \\
\hline Natural Sciences & $-0.084^{\star *}$ & -7.663 \\
\hline Mathematics & $0.086^{\star \star}$ & 6.590 \\
\hline Medical Sciences & $0.067^{\star \star}$ & 5.495 \\
\hline Universities vs. H.E. Institutions & $0.030^{\star *}$ & 4.337 \\
\hline
\end{tabular}

- $p \leq .05$ and ${ }^{* *} p \leq .01$ (effects of country dummies not shown).

\section{Effects of competences on job satisfaction}

The effects of competences on job satisfaction are shown in Table 4. To reflect the ordinal character of the answers on job satisfaction, we used the ordered probit model. To facilitate a comparison with the effects on income, the same set of explanatory variables used in the previous analysis has been included here as well. Additionally, gross annual income has also been included as a key determinant of job satisfaction.

The model shows that job satisfaction was strongly influenced by the required level of competences. We observe that high requirements in generic, participative, specialised, 
organisational and socio-emotional competences were associated to positive effects on job satisfaction. However, the opposite effect was found for applying-rules competences. With respect to the rest of the control variables, we found that there was a negative effect from age predicted by conventional literature (Clark \& Oswald 1996). As one might expect, income had quite a strong, positive effect on job satisfaction. Those graduates working in a small firm and holding a permanent contract were also more satisfied than those working for large firms and holding fix-term contracts. Public sector workers were more satisfied than private sector ones. With respect to occupational titles, results provide evidence showing that individuals working in more complex jobs were more satisfied than their colleagues in simpler jobs. Legislators, senior officials, managers, professionals, technicians and associate professionals were more satisfied than their counterparts in elementary occupations. It could be said that higher-level jobs tend to be more complex and have better working conditions, pay, promotion prospects, supervision, autonomy and responsibility, and that all this characteristics are positively associated with job satisfaction. On the other hand, graduates in Humanities, Social Sciences and Law were less satisfied in their jobs with respect to the reference category (Engineering). Mathematics graduates were the most satisfied in their jobs. Finally, having followed university education rather than other higher education institutions increased the level of job satisfaction as well. 
Table 4. Ordered Probit Estimates for Job Satisfaction.

\begin{tabular}{|c|c|c|}
\hline 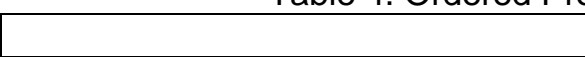 & Coeff. & t-values \\
\hline \multicolumn{3}{|l|}{ Required Competences } \\
\hline Participative & $0.169 * \star$ & 21.609 \\
\hline Methodological & $0.058^{\star *}$ & 7.072 \\
\hline Specialised & $0.153^{\star \star}$ & 19.192 \\
\hline Organisational & $0.105^{\star \star}$ & 13.303 \\
\hline Applying-rules & $-0.093^{\star \star}$ & -11.576 \\
\hline Physical & $0.017^{*}$ & 2.077 \\
\hline Generic & $0.193^{\star *}$ & 24.366 \\
\hline Socio-emotional & $0.127^{\star \star}$ & 15.851 \\
\hline \multicolumn{3}{|l|}{ Personal Characteristics } \\
\hline Female & -0.003 & -0.210 \\
\hline Age & $-0.038^{\star \star}$ & -10.259 \\
\hline \multicolumn{3}{|l|}{ Job Characteristics } \\
\hline Annual gross income & $0.331^{* *}$ & 20.167 \\
\hline Hours worked per week & 0.045 & 1.294 \\
\hline Private sector & $-0.172^{\star \star}$ & -10.142 \\
\hline Small firm & $0.094^{\star *}$ & 5.235 \\
\hline Full-time job & 0.026 & 0.860 \\
\hline Permanent contract & $0.125^{\star \star}$ & 6.650 \\
\hline \multicolumn{3}{|c|}{ Occupational titles (ref. elementary occupations) } \\
\hline Legislators, senior official and managers & $0.176^{\star \star}$ & 5.947 \\
\hline Professionals & $0.212^{\star \star}$ & 9.682 \\
\hline Technicians and associate professionals & $0.134^{\star \star}$ & 4.945 \\
\hline Clerks & $-0.075^{\star}$ & -1.977 \\
\hline Service workers & 0.023 & 0.396 \\
\hline \multicolumn{3}{|l|}{ Field of Study (ref. engineering) } \\
\hline Education & -0.033 & -0.924 \\
\hline Humanities & $-0.112^{\star \star}$ & -4.180 \\
\hline Social Sciences & $-0.056^{\star *}$ & -2.701 \\
\hline Law & $-0.096 * *$ & -3.034 \\
\hline Natural Sciences & 0.005 & 0.183 \\
\hline Mathematics & $0.139 * \star$ & 4.142 \\
\hline Medical Sciences & -0.044 & -1.410 \\
\hline Universities vs. H.E. Institutions & $0.090^{\star *}$ & 5.088 \\
\hline Observations & \multicolumn{2}{|c|}{24,414} \\
\hline
\end{tabular}

${ }^{*} p \leq .05$ and ${ }^{* *} p \leq .01$ (effects of country dummies not shown).

\section{CONCLUSIONS}

Eight different categories of human capital competences, emerging from factor analysis of 36 characteristics surveyed, were explored in this paper, namely participative, methodological, specialised, organisational, applying-rules, physical, generic and socioemotional competences to provide a more detailed analysis of the different roles and rewards of the competences in the labour market. Other variables such as personal characteristics, job attributes, occupational titles, field of study and the distinction of graduates from university 
institutions versus those from other higher education institutions have been considered as explanatory variables. Control dummies for the eleven European countries of our sample were also taken into account.

Our findings about income rewards suggest that those jobs with higher requirement of participative and methodological competences were the best paid. On the contrary, jobs with higher requirements of organisational, applying-rules and physical competences were the worst paid. The explanation for the case of physical competences is evident: they are demanded in jobs that are under-qualified jobs for higher education graduates. With respect to specialised competences, it is ironic, though not surprising, that jobs where specialised competences (that is, those related to field specific knowledge) were highly required but not better paid. It is likely that these are more traditional jobs, in many cases in the public sector, having lower salaries at least at the beginning of the career. In summary, we observe that the monetary reward for jobs depended more on competences related to the capacity of the individual to manage a complex situation with leadership and personal involvement than to the specific knowledge needed in the jobs. Attitudes towards work (instead of knowledge) were the most rewarded characteristics in the labour market for young graduates.

Our results related to job satisfaction suggested that working in a job requiring high levels of competences increased graduates' satisfaction. Nevertheless, this was not true for all types of competences, the exception being applying-rules competences.

Finally, we found that female graduates earned less, but they were as satisfied as their male counterparts on their jobs, consistently with earlier work in this area. In addition, European young graduates earned more with permanent and full-time jobs in the private sector and large firms, although they preferred jobs in the public sector and small firms in terms of satisfaction. Nevertheless, a good salary was the capital single element for increasing job satisfaction. Higher-level jobs were more rewarding, since they were related to both high-income and high-level of satisfaction. Fields such as Mathematics, Engineering and Medical Sciences generated the highest incomes and the highest levels of job satisfaction. Having graduated from university education rather than from other higher education institutions also increased both income and job satisfaction.

It must be remarked that we have only considered the required competences. This means that we have analysed income and job satisfaction in regard to the job itself and not to the 
real competences of the individuals. Consequently, our analysis describes the demand of competences by the labour market but not the possible mismatch between acquired and required competences. In consequence, recommendations to the higher education institutions must be taken carefully. Further research must be done in this sense and a new European survey (the REFLEX project) has been initiated with this goal.

Nevertheless, we can conclude from our results that the current labour market for young graduates is changing. Traditionally, at least in most European countries, theoretical and specific knowledge were the keys for reaching a high professional position related to a higher education diploma. A new and more dynamic labour market, on one hand, and the massive presence of higher education graduates on the labour market, on the other hand, has created a new situation where these competences are not anymore the most demanded (considering monetary rewards as the proxy of demand) in the labour market. The new situation requires individuals with participative, methodological, generic and socio-emotional competences. Enhancing these competences in the educational process require a different approach form the higher education institutions more focused on active learning, stimulation of relationships and cooperation of individuals, promoting multidisciplinary approaches and so on. In summary, the current social demand requires a different style for the learning process far away of the traditional methods based on the passive accumulation of knowledge by students.

\section{REFERENCES}

Allen, J. \& Van der Velden, R. (2001): Educational Mismatches versus Skill Mismatches: Effects on Wages, Job Satisfaction and On-the-job Search, Oxford Economic Papers, 53(3): 434-452.

Arrow, K. (1997): The Benefits of Education and the Formation of Preferences, in J. R. Behrman and N. Stacy (eds.): The Social Benefits of Education. Ann Arbor: University of Michigan Press.

Becker, G.S. (1993): Human Capital: A Theoretical and Empirical Analysis with Special Relevance to Education, Columbia University Press, NBER, New York.

Becker, G.S. (1964): Human Capital - A Theoretical and Empirical Analysis, with Special Reference to Education, New York, National Bureau of Economic Research, Columbia University Press.

Belfield, C.R., Bullock, A.D. \& Fielding, A. (1999): Graduates' Views on the Contribution of Their Higher Education to Their General Development: A Retrospective Evaluation for the United Kingdom, Research in Higher Education, 40(4): 409-438. 
Bishop, J.H. (1995): Vocational Education and At-Risk Youth in the United States, Vocational Training European Journal, 6: 34-42.

Bishop, J.H., Kang, D. (1989): Vocational and Academic Education in High School: Complements or Substitutes?, Economics of Education Review, 8(2): 133-148.

Bowen, H.R. (1977): Investment in Learning, San Francisco: Jossey-Bass Inc.

Buchel, F. (2002): The Effects of Overeducation on Productivity in Germany - The Firms' Viewpoint, Economics of Education Review, 21: 263-275.

Bunk, G.P. (1994): Teaching Competence in Initial and Continuing Vocational Training in the Federal Republic of Germany, Vocational Training European Journal, 1: 8-14.

Busato, V.V., Prins, F.J., Elshout, J.J. \& Hamaker, C. (2000): Intellectual Ability, Learning Style, Personality, Achievement Motivation and Academic Success of Psychology Students in Higher Education, Personality and Individual Differences, 29: 1057-1068.

Card, D. (1999): The Causal Effect on Education on Earnings, in O. Ashenfelter and D. Card (eds.), Handbook of Labor Economics, Volume 3. Amsterdam: Elsevier Science B.V.

Campbell, P.B. \& Laughlin, S. (1991): Participation in Vocational Education: An Overview of Patterns and Their Outcomes, Columbus, In: National Centre for Research in Vocational Education.

Clark, A. E. \& Oswald, A. J. (1996): Satisfaction and Comparison Income, Journal of Public Economics, 61: 359381.

Cohn, E. \& Addison, J.T. (1998): The Economic Returns to Lifelong Learning in OECD Countries. Education Economics, 6(3): 253-307.

Dolton, P.J. \& Makepeace, G.M. (1990): Graduate Earnings After Six Years: Who are the Winners?, Studies in Higher Education, 15(1): 31-55.

Green, W. H. (1997): Econometric Analysis, third edition, Prentice-Hall, New Jersey.

Hartog, J. (1992): Capabilities, Allocation and Earnings, Kluwer, Boston.

Haveman, R. H. \& Wolfe, B. L. (1984): Schooling and Economic Well-Being: The Role of Nonmarket Effects, Journal of Human Resources, 19(3): 378-407.

Heijke, H., Meng, C. \& Ramaekers, G. (2002): An Investigation into the Role of Human Capital Competences and Their Pay-Off, Research Memorandum, ROA, Maastricht.

Iyigun, M. F. \& Owen, A. L. (1999): Entrepreneurs, Professionals and Growth, Journal of Economic Growth, 4: 213-232.

Kellermann, P. (2003): Acquired and Required Competencies of Graduates, in Teichler, U. (ed.), Careers of University Graduates: Views and Experiences in Comparative Perspectives. Dordrecht: Kluwer (in press).

Kettunen, J. (1997): Education and Unemployment Duration, Economics of Education Review, 16(2): 163-170. 
Kiefer, N. (1985): Evidence on the Role of Education on Labor Turnover, Journal of Human Resources, 20(3): 445-452.

McMahon, W. (1998): Conceptual Framework for the Analysis of the Social Benefits of Lifelong Learning. Education Economics, 6(3): 309-346.

Nordhaug, O. (1993): Human Capital in Organizations, Competence, Training and Learning, Oxford University Press, Bergen.

Leckey, J.F. \& McGuigan (1997): Right Tracks-Wrong Rails: The Development of Generic Skills in Higher Education, Research in Higher Education, 38(3): 365-378.

Pike, G.R. (1995): The Relationship Between Self-Reports of College Experiences and Achievement Test Scores, Research in Higher Education, 36(1):1-22.

Psacharopoulos, G. (1994): Returns to Investment in Education: A Global Update. World Development, 22(9): 1325-1343.

Rivera-Batiz, F. L. (1992): Quantitative Literacy and the Likelihood of Employment Among Young Adults in the United States, Journal of Human Resources, 27(2): 318-328.

Schomburg, H. \& Teichler, U. (2004): Higher Education and Graduate Employment in Europe: Results of Graduate Survey from Twelve Countries, Kluwer Pub. (in press).

Teichler, U. \& Schomburg, H. (2004): Careers of Higher Education Graduates, View and Experiences in Comparative Perspectives, Kluwer Pub. (in press).

Teichler, U. \& Kehm, B. (1995): Towards a New Understanding of the Relationships Between Higher Education and Employment, European Journal of Education, 30(2): 115-132.

Thurow, L.C. (1975): Generating inequality, New York: Basic Books.

Weisbrod, B.A. (1964): External Benefits of Public Education: An Economic Analysis, Research Report, 105: 1143.

Witte, J.C. \& Kalleberg, A.L. (1995): Matching Training and Jobs: The Fit Between Vocational Education and Employment in the German Labor Market, European Sociological Review, 11(3): 293-317.

Adela Garcia-Aracil

Technical University of Valencia

Jose-Gines Mora

Director

Centre for Higher Education Management (CHEM)
Luis E. Vila

University of Valencia 
Technical University of Valencia

Rectorate

Camino de Vera

46022 Valencia

Spain

Tel: 34963879094

Email: josegines@upv.es 